\title{
Diet, nutrition, and cancer risk: what do we know and what is the way forward?
}

(c) (1) $\Theta$ OPEN ACCESS

In this analysis (BMJ 2020;368:m511, doi:10.1136/bmj.m511),

Shoichiro Tsugane's job title was incorrect-it should be

director, not section head. This has been corrected online. 